\begin{abstract}
Показана перспективність створення ефективних та рентабельних органічних мультитекстур для фронтальної поверхні гібридної структури сонячних елементів золь-гель-методом на макро- або мезапоруватому кремнію. Розробка технологічного процесу синтезу золь-гель методу була проведена з використанням низькомолекулярного полімеру з нанесенням АВ поверхней ксерогелів поліорганосилоксанів. Параметри багатофункціональної органічної мультитекстури були досліджені методом мас-спектрометрії
\end{abstract}

Ключові слова: сонячний елемент, поруватий кремній, гібридна структура, золь-гель покриття, багатофункціональна мультитекстура

Показана перспективность создания әффективных и рентабельных органических мультитекстур для фронтальной поверхности гибридной структуры солнечных элементов золь-гель методом на макро- или мезапористом кремнии. Разработка технологического процесса синтеза золь-гель метода была проведена с использованием низкомолекулярного полимера с нанесением АО поверхностей - ксерогелей полиорганосилоксанов. Параметры многофункциональной органической мультитекстуры были исследованы методом масс-спектрометрии

Ключевые слова: солнечный элемент, пористый кремний, гибридная структура, золь-гель покриття, многофункциональная мультитекстура
UDC 621.315 .592

DOI: $10.15587 / 1729-4061.2017 .103820$

\title{
DEVELOPING THE MULTITEXTURE OF HYBRID STRUCTURE OF A SOLAR CELL
}

\author{
V. Yerokhov \\ Doctor of Technical Sciences, \\ Associate Professor \\ Department of Semiconductor Electronics \\ Lviv Polytechnic National University \\ S. Bandery str., 12, Lviv, Ukraine, 79013 \\ E-mail:v.yerokhov@gmail.com
}

\section{Introduction}

At present, the needs of humanity in energy are constantly growing. However, already in the nearest decades, energy producers will face a shortage of natural fuel (oil, gas, coal). In addition, there may occur a problem of catastrophic pollution of the environment caused by burning this fuel, as well as the potential danger of nuclear power generation. Therefore, there is a necessity to obtain cheap energy using renewable power sources with minimal impact on the environment [1]. That is why now the so-called "non-traditional" or "clean" energy is gaining traction, which employs virtually inexhaustible resources [2].

World photovoltaics is one of the most promising sectors of modern industry, rapidly developing, which in recent years has experienced one of the large increases in the production of electricity. Prices for traditional energy sources are constantly growing, due to the growth of the world population, intensive growth of consumption of industrial production of energy. The desire to reduce cost and enhance the technical and photovoltaic parameters leads to the development of new systems, more numerous and comprehensive in this area. In this case, over the last decade, most ground-based photovoltaic systems have been designed based on crystalline silicon with a mean value of conversion efficiency at $\eta \approx 16-18-20 \%$.

Photovoltaics is the most elegant technique for electricity generation without moving parts, gas release or noise. Moreover, all this is possible when converting an infinite amount of solar energy. This has become the impetus for the development of high power solar energy that could compete with traditional methods of generating electricity in order to meet energy needs of humanity.
Solar cells (SC) have confirmed their indispensability, high reliability and durability when operating both aboard the spacecraft and in the construction of large ground-based solar plants and in photovoltaic panels on our walls and roofs.

High efficiency, technological simplicity, low cost of fabrication and sufficient degradation resistance are mandatory criteria to the SC of ground-based photovoltaics at all levels. In the large-scale use, today's SCs do not comply in full with the specified requirements and remain insufficiently profitable [1, 2].

All SC have different structure. The only drawback is the high price of such structures at high degradation. Creation of multi-functional organic multitexture on the frontal surface of a photoelectric converter using the hybrid technologies will reduce the cost and improve the technical and the photovoltaic parameters of SC.

Intensive development of modern photovoltaics requires extensive research and application of new materials and technologies. Development and creation of modern SC depends in many respects on the advances technologies. This is, first of all, a synthesis of materials and the application of new types of films [1]. Such coatings can be used as texture and anti-reflective coatings (ARC) of SC with their optimal use. These coatings are used in photovoltaics as elements of the structure of SC, as brightening and protective coatings, etc.

Among known technological techniques for the formation of coatings with the required physical-chemical properties, of great interest is the sol-gel process. This method implies formation of coating on a silicon substrate from colloidal solution by centrifugation or immersion of the substrate of a would-be SC into a film-forming organic solution. During subsequent thermal treatment, it is possible to re- 
ceive from it a solid organic film with parameters (thickness, porosity, etc.) that are determined by technological process. Controlled introduction of additional components to the film-forming organic solution makes it possible to change the properties of the coatings obtained from them. Technological process can change the required optical and electrical-physical parameters (chemical composition, coefficient of thermal expansion, etc.), that is, it is possible to easily modify the properties of the resulting product [2].

Over the last decade, increased attention has been paid to photovoltaic devices with organic components. If we compare technologies based on different silicon solar cells, it is possible to see that very different technologies complement each other in many cases. Some technologies propose low cost, low coefficient of heat budget, different treatment with a solution, flexible substrates and very high speed of treatment. Until recently, solar cells based on pure silicon solar cells had advantages in effectiveness and operation life cycle of a device, as well as in device performance efficiency that exceeded $20 \%$, while degradation for multi- and monocrystalline silicon SC (in the form of standard solar panels) at work in the open air (roofs and walls of buildings, etc.) withstood more than 25 years.

It should be emphasized that the high efficiency and long life cycle is not observed for the same SC with organic material, and one of the current problems is the combination of all of the desired properties in the same material (efficiency, stability, manufacturability and low cost) [3].

\section{Literature review and problem statement}

Several methods of obtaining a textured surface of silicon substrates were developed for the subsequent usage in SC [4]. The most known and widely used method is anisotropic etching of the surface of silicon substrates in a $10 \%$ aqueous solution of $\mathrm{KOH}$ with obtaining pyramid textures. Highly efficient textures can also be received using the electrochemical method or anodizing under direct current in hydrofluoric electrolytes, as well as the method of chemical etching of silicon substrates in a mixture of hydrofluoric and nitric acid $\left(\mathrm{HF}-\mathrm{HNO}_{3}\right)$ with defined components [5].

At present, we are aware of a number of more advanced methods to obtain the layers of porous silicon (PS) [6], although widely used is the electrochemical method only, or anodizing under direct current in electrolytes based on $\mathrm{HF}$, and the chemical method or coloring etching in $\mathrm{HF}-\mathrm{HNO}_{3}-$ electrolytes.

Among many benefits, the electrochemical method has several significant disadvantages. Among them is the need to create quality wire contact on the backside of each of the samples and the appropriate equipment to create a finished electrode system, in which direct current source is always present as a component [7]. This contact on the backside of a silicon wafer does not subsequently fit the technological process of creation of silicon solar cells, that is, it requires additional operations to prepare the backside (back contact) of a plate for the resulting product. Large areas of surfaces of SC substrates may require currents up to hundreds of amperes. Resolving such a task is a rather complicated technological problem. That is why there are certain constraints in the industrial application of electrochemical method for carrying out a complete technological cycle for manufacturing electronic devices with PS.
The chemical etching in turn does not need a source of direct current and, hence, creation of any back contact. Underlying a chemical process of etching are the electrochemical reactions that occur on the surface of Si substrate and in the near-surface layer of electrolyte. Technological process of fabricating PS using this method is maximally simple and implies as the basis the immersion of samples into electrolyte, with the purpose of conducting the process of etching with subsequent removal of residual acids, washing and drying. Given these considerations, the chemical (coloring) etching is potentially a very promising technological direction to create porous structures $[8,9]$. That is why this method can replace the electrochemical etching at certain stages of the production of electronic devices and devices for photovoltaic and optoelectronic use with PS [10].

A new, simple and reproducible method of etching termed "Ag-Assisted" - Method of Chemical Vapor-Phase Etching (Ag-ACVE) - is reported in this work. It proposes to expose Ag-treated silicon substrates to vapors that are released from $\mathrm{HF}$ /hot solution of $\mathrm{H}_{2} \mathrm{O}_{2}$. Surface treatment carried out using this method is aimed at improving optical and electrical properties of conventional silicon solar cells [11].

Two methods of texturing using pyramids and PS have been applied to investigate their influence on the performance of crystalline silicon (c-Si) solar cells [12].

Electrochemical etching is conducted to obtain PC based on crystalline silicon of the n-type with substrates (100) and (111). They used etching several times for 10, 20 and 30 minutes. Porous silicon layer was used as an anti-reflective coating for crystalline silicon solar cells. Optimal etching time equaled 20 minutes to obtain porous silicon layers based on crystalline silicon of the n-type with substrates (100) and (111). Nanopores with high porosity were made on a porous layer of silicon based on crystalline silicon of the n-type with substrates (100) and (111) with a mean diameter of 5.7 and $5.8 \mathrm{~nm}$, respectively [13].

Creation of a multifunctional device based on combining photoelectric conversion and sensitivity of toxic gases is reported in article [14]. In this device, the membranes on carbon nanotubes (CNT) are used to cover arrays of silicon nanowires (SiNW) to form a heterojunction. The porous structure and a large specific surface area in the structure of a heterojunction are two advantages for the adsorption of gases. Improving performance of the element is one of the main advantages when using a proper method of alloying by gas. The device can also work with an autonomous power of gas sensor without a solar cells.

A new hybrid structure for improving the efficiency of crystalline silicon solar cells is proposed in paper [15]. Calculations demonstrated that the nanoporous silicon (np-Si) while filling in the polythiophenes inside the pores displays a significantly higher absorption coefficient compared to that without it. This makes the nanoporous silicon with pores that are filled with polythiophenes, a truly magic material that absorbs light.

The synthesis of nanohybrid materials from film-forming colloidal solutions is carried out by using a sol-gel transition or gel-formation. Sols are a dispersion of colloidal particles the size of 1-100 nanometers in a fluid. This process can also be used for hybrid structures of solar cells [16]. Gel-formation is predetermined by the emergence in the volume of the liquid system of molecular grid or a frame of interconnected polymeric chains of micron size and submicron pores. Gel-formation eliminates the system's fluidity and renders 
it some solid-state properties (strength, fragility, etc.). The term "gel" covers a variety of substances. The term "polymerization" means binding of individual monomers, at which a polymer forms with the composition similar to the monomer. Note that during these processes the condensed monomer $\mathrm{M}(\mathrm{OH})_{4}$ creates a polymer with composition of $\left(\mathrm{MO}_{2}\right)_{\mathrm{n}}$. Commonly applied term "polymerization" is also used to describe the processes of film-formation from colloidal solutions.

It was established experimentally that the upper limit for the size of particles of silica sol did not exceed $5 \mathrm{~nm}$. Beyond this limit, there occurs the process of gel-formation and silicasol is converted to silicagel [17]. Thus, a gel is a state of a substance that is intermediate between the solid and the liquid, the so-called fluid-like solid state. Silicagel is derived from the multitude of discrete colloidal particles or by forming an interconnected three-dimensional chain at simultaneous progress of hydrolysis and poly-condensation of organometallic film-formation.

\section{Research goal and objectives}

The goal of present study is to create efficient and profitable organic multitextures for the frontal surface of a hybrid structure of solar cells by the sol-gel method on the macro- or mesoporous silicon.

To accomplish the goal, the following tasks have been set:

- to explore and develop a chemical process of receiving macro- and mesoporous texture on a silicon substrate for the frontal surface of a hybrid structure of solar cells;

to develop, for the resulting macro- or mesoporous texture of a silicon substrate of the frontal surface of a hybrid structure of solar cells, an anti-reflective organic multilayer stack. For this purpose, by using a low-molecular polymer, which represents the spatially-crosslinked condensation structures of silicon-organic gel, to create xerogels of polyorganosiloxanes;

- to explore the resulting multifunctional organic multitexture-xerogel, created at the macro surface of silicon substrate by the method of mass spectrometry.

\section{Study and development of a chemical process of receiving macro- and mesoporous texture on a silicon substrate}

Electrolytes used for chemical etching are mainly made based on a mixture of $\mathrm{HF}-\mathrm{HNO}_{3}$ acids in typical ratios [18]. Common chemical reagents are used as a basic etchant ( $49 \% \mathrm{HF}$ and $70-71 \% \mathrm{HNO}_{3}$ ); deionized water as a solvent. Acetic acid in electrolytes can also be used as a solvent and serve as auxiliary, that is, with water, and the main solvent without water. The function of acetic acid $\left(\mathrm{CH}_{3} \mathrm{COOH}\right)$ is to reduce the concentration of reagents in the electrolyte and it does not take any participation in the chemical reaction with the surface of a silicone substrate. However, acetic acid provides a more even growth of PS on the surface due to the reduction in surface tension of the solution, which, in turn, improves wettability of the surface. In addition, acetic acid may play the role of a buffer reagent and it possesses a lower dielectric permeability than water. Similar characteristics are typical for ethanol, which, similar to acetic acid, is sometimes used in electrolytes with content of $\sim 3 \%$.
The growth of PS using chemical method occurs mostly in specialized teflon reactors, with or without agitation, at different types and power of illumination. Growth occurs on both sides simultaneously. Macroporous surfaces, formed in electrolytes based on $\mathrm{HF}-\mathrm{HNO}_{3}$, are similar in physical appearance to the surfaces, which are made using traditional anodizing. Layers of PS are similar in physical appearance to the surfaces that are made in the electrolytes based on $\mathrm{HF}-\mathrm{HNO}_{3}$, and by using electrochemical anodizing, which in turn indicates the similarity of the mechanisms of PS creation. PS may be obtained on substrates with arbitrary type of conductivity, degree of doping and areas of surfaces [19,20].

In general, the process of etching the surface of Si consists of two stages. At the first stage, the surface of $\mathrm{Si} / \mathrm{HNO}_{3}$ is oxidized by an oxidizing reagent. The next step is the oxide reduction of $\mathrm{HF}$ - by a complexing agent, with the subsequent creation of water-soluble form of the complex $\mathrm{H}_{2} \mathrm{SiF}_{6}$ and water [21].

Mechanisms that describe the formation of layers of PS are based on the principles of chemical etching of a Si surface [22]. Chemical etching should be regarded as a localized electrochemical process. That is, on the energetically favorable areas of the surface (places of physical and chemical irregularities), microscopic localized anodes and cathodes are formed with current flow between them, the electrolyte acts as the primary medium. There are two processes on the anode: this is the oxidation of $\mathrm{Si}$ and its further reduction, while on the cathode there occurs the restoration of oxidizer, as a result of which nitrous acid $\left(\mathrm{HNO}_{2}\right)$ forms, which is a stronger oxidizer than $\mathrm{HNO}_{3}$.

Associated processes that occur on the micro anode and micro cathode areas of the surface during etching of a silicon surface in the mixture of acids $\mathrm{HF}-\mathrm{HNO}_{3}$ can be described by general equation (1):

$$
\mathrm{Si}+\mathrm{HNO}_{3}+6 \mathrm{HF}=\mathrm{H}_{2} \mathrm{SiF}_{6}+\mathrm{HNO}_{2}+\mathrm{H}_{2} \mathrm{O}+\mathrm{H}_{2} .
$$

It is implied that $\mathrm{HNO}_{3}$ is restored to nitrogen monoxide $\mathrm{NO}$ and, according to study into molar ratio of acids in a solution, we receive (2):

$$
3 \mathrm{Si}+4 \mathrm{HNO}_{3}+18 \mathrm{HF}=3 \mathrm{H}_{2} \mathrm{SiF}_{6}+4 \mathrm{NO}+8 \mathrm{H}_{2} \mathrm{O} .
$$

The location of the micro anode and micro cathode areas, which are predominantly the dislocated formations and boundaries between grains, in the process of etching $\mathrm{Si}$ are not stable or fixed on the surface. There only happens certain alternating between the anode and cathode states in the local area.

Oxidizing ability of $\mathrm{HNO}_{3}$ is proportional to the concentration of non-dissociated $\mathrm{HNO}_{3}$ in the solution. Cathode reaction by its nature is autocatalytic and waiting time (initialization time) of the onset of reaction actually causes self-catalytic growth of the required concentration of oxidizing reagent $\mathrm{HNO}_{2}$. Initializing time $\mathrm{t}_{\mathrm{L}}$ includes two stages: beginning of the process of etching by adsorbing of sufficient concentration of $\mathrm{HNO}_{2}$; initializing the process of selective etching by reducing the speed of the process of electrode switch. By comparing the times of initialization for silicon doped with phosphorus and boron, it was discovered that the time of incubation for the latter was significantly less. For $\mathrm{p}-\mathrm{Si}$, we observed a growth in the time of incubation in line with a decrease in the level of doping from $t_{\mathrm{L}} \sim 0.5 \mathrm{~min}$ for plates with conductivity $\rho \sim 0.001 \mathrm{Ohm} \cdot \mathrm{cm}$ to $\mathrm{t}_{\mathrm{L}} \sim 9 \mathrm{~min}$ for plates with conductivity $\rho \sim 40 \mathrm{Ohm} \cdot \mathrm{cm}$. For $\mathrm{n}-\mathrm{Si}$, we 
observed a direct dependence, that is, with increasing level of doping, there is an increase in the time of incubation from $\mathrm{t}_{\mathrm{L}} \sim 8 \mathrm{~min}$ for plates with conductivity $\rho \sim 10 \mathrm{Ohm} \cdot \mathrm{cm}$ to $\mathrm{t}_{\mathrm{L}} \sim 10 \mathrm{~min}$ for plates with conductivity $\rho \sim 0.1 \mathrm{Ohm} \cdot \mathrm{cm}$. These results are in a good agreement with the basic principles of etching a Si surface. It should be noted that the samples of p-Si are almost not affected by illumination, while the n-Si samples display an increase in the time of incubation at UV illumination.

The reaction starts almost instantly in the concentrations of nitric acid exceeding $40 \%$; in general, a shorter incubation time is inherent for the solutions with a high content of $\mathrm{HNO}_{3}$. In this case, the impact of $\mathrm{HF}$ acid is negligible, except for the extreme value of its content in the solution of $\mathrm{HF}<5 \%$. Sufficiently intensive agitation helps reduce the incubation time by a decrease in the absorbing ability of limiting speeds of $\mathrm{HNO}_{2}$ compounds. However, on the other hand, conditions of agitation significantly enough affect the resulting thickness of the obtained surfaces. Following the onset of reaction, porous film grows quite quickly, but the growth in depth stops in several minutes. The resulting thickness of the growing surface is determined by balancing the speeds of etching of silicon in the top and bottom surface of the porous layer. Under conditions of the more intensive agitation, the rougher surface grows. The magnitude of the inactive layer of a silicon surface is reduced. This, in turn, increases the diffusion of reagents and reaction products between the volume of the solution and the surface of the substrate of Si. It should also be noted that different specific resistances of substrates are characterized by their resulting thickness of a porous surface [23].

The task of obtaining the desired size and depth of the textures is actually two subtasks (conditions), which must be solved simultaneously within a single technological process. Diameter of the pores may vary in a wide range of values $2 \ldots 25 \mu \mathrm{m}$ (Fig. 1), with the depth of a pore limited by the so-called "wear and tear" of the material during etching. With a decrease in the thickness of silicon substrates, the formation of deep pores will have a negative impact on the mechanical properties of a SC substrate, increasing the cost of SC fabrication.

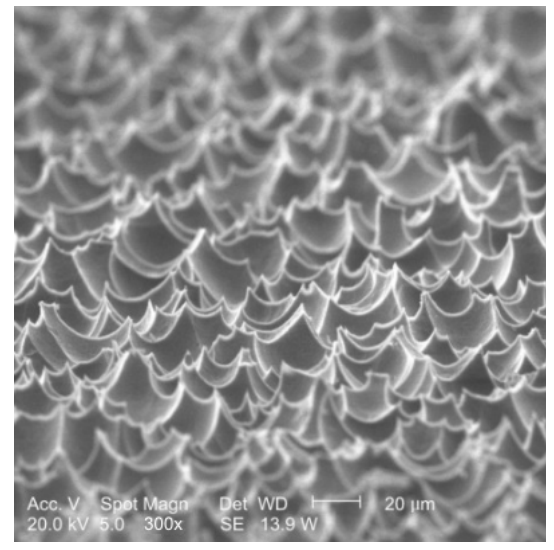

Fig. 1. Image of the macro surface of texture for SC created by the methods of chemical etching of silicon multicrystalline substrate

To prepare etchants, we used hydrofluoric acid with a concentration of $40 \%$ and nitric acid with a concentration of $68 \%$, dimethylformamide, and distilled water. Studies have shown that the solutions of acids without introduction of additions are not sufficiently effective. Lack of additions leads to a situation when the surface shapes with low coefficient of reflection are not formed. Large values of the speeds of etching do not make it possible to receive pores of the specified size.

It was found that adding a small amount of sodium salt of nitrade acid leads to a significant inhibition of the processes of chemical interaction over first $30 \mathrm{~s}$, and then to a rapid increase in the speed of etching. However, this process is also not enough efficient due to the low depth (to $10 \mu \mathrm{m}$ ) of the obtained pores. The depth of the pores can be increased by adding to the solution of surface activator, by reducing the interphase energy and improving the diffusion of components to the surface of interphase boundary. The substances that improve surface activity by reducing the surface tension of the solution at the interphase boundary include organic substances. Such substances contain in their structure a polar group and a nonpolar hydrocarbon radical (Fig. 2).

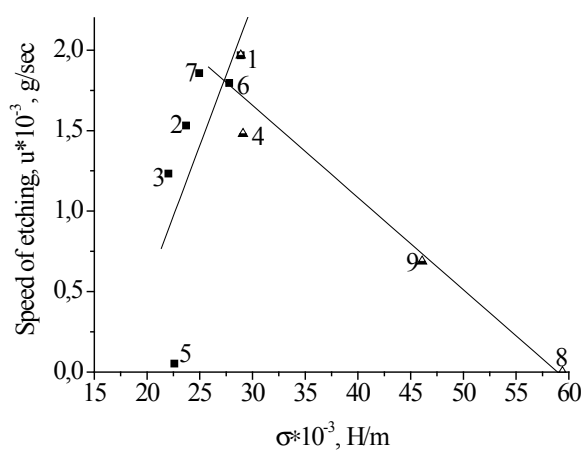

Fig. 2. Dependence of the mean speed of etching on the magnitude of surface tension of additions of organic origin ( $\mathrm{T}=$ room, $\mathrm{t}=90 \mathrm{~s}, \mathrm{~V}=10 \mathrm{ml}, \mathrm{m}_{\mathrm{s}}=0.2 \mathrm{~g}$ ). Electrolyte: $\mathrm{HF}(40 \%): \mathrm{HNO}_{3}(68 \%): \mathrm{H}_{2} \mathrm{O}$ (distil.) $=10: 5: 1+\mathrm{NaNO}_{2}$ (small amount). Additions of organic origin: $1-\mathrm{C}_{6} \mathrm{H}_{6}: 0.4$;

$2-\mathrm{C}_{3} \mathrm{H}_{6} \mathrm{O}: 0.4 ; 3-\mathrm{C}_{2} \mathrm{H}_{5} \mathrm{OH}: 0.4 ; 4-\mathrm{CH}_{3} \mathrm{CN}: 0.4$;

$5-\mathrm{CH}_{3} \mathrm{OH}: 0.4 ; 6-\mathrm{CH}_{3} \mathrm{COOH}: 0.4 ; 7-\mathrm{C}_{6} \mathrm{H}_{12}: 0.4$; $8-\mathrm{C}_{3} \mathrm{H}_{8} \mathrm{O}_{3}: 0.4 ; 9-\mathrm{C}_{2} \mathrm{H}_{6} \mathrm{O}_{2}: 0.4$

Results of examining an impact of the value of surface tension of additions of organic origin (organic acids, ketones, alcohols) are shown in Fig. 2. It should be noted that at values of surface tension of $20 \ldots 30 \mathrm{~N} / \mathrm{m}$, the mean speed of etching increases at first and then decreases. This is due to the presence of groups of $\mathrm{CH}_{3}$ in the structure of organic substances, which positively affect the speed of etching, whereas the groups of $\mathrm{OH}^{-}$are, on the contrary, not desirable.

Fig. 2 shows experimental dependence of the speed of etching on dielectric permeability for etchants with different groups of components of organic origin. The strongest interactions take place during occurrence of intermolecular hydrogen bonds and donor-acceptor complexes. In addition, the interaction of molecules of solvent with one another due to a dipole-dipole attraction leads to the fact that the solvent is not an absolutely homogeneous medium, and has a certain structure. Dimethylformamide DMFA $\left(\left(\mathrm{CH}_{3}\right)_{2} \mathrm{NCOH}\right)$ actually belongs to the group of aprotic bipolar (dipole) solvents with a high dipole moment and a rather high dielectric conductivity $(\varepsilon=36.7)$, capable of forming strong donor-acceptor complexes. 


\section{Synthesis of sol-gel technologies for multifunctional multitextures}

We obtained organosilicon xerogels (represented by technological steps) (Fig. 3), porous polyorganosiloxanes that are released during hydrolysis and poly-condensation of three-functional organosilicon compounds when conditions of the reaction contribute to the creation of oversaturated solutions of polyorganosiloxanes. Such colloid-chemical systems form over time a spatially-crosslinked structure of silicon-organic gel.

At the molecular level, formation of a gel from solutions containing metal alkoxides is accompanied by reactions of hydrolysis and poly-condensation.

When removing liquid from a gel during thermal treatment under conditions of atmospheric pressure, or close to it, the gel shrinks and forms a monolith, named xerogel. During subsequent thermal treatment, porous gel turns to glass, ceramics or a porous solid body. The primary structure of gel has a significant impact on the formation of its subsequent structure at drying. That is why xerogel partially preserves the structural properties of moist gel (that is, gel prior to drying), such as porosity, dimensions and distribution of pores, density of the matrix, as well as contains structural changes caused by drying. Subsequent processes of compaction and crystallization will depend on the chemical composition of xerogel, surface area, porosity and others. Thus, in the evolutionary chain of the system sol-gel-xerogel, properties of the next link depend on the previous one.

Sol-gel method makes it possible to receive the films of xerogels, applied by immersion or centrifugation. The method of centrifugation of film-forming solutions is very attractive, as it gives the possibility to create a relatively homogeneous film of thickness $\sim 0.1 \mu \mathrm{m}$ on a wafer of large enough diameter [16].

Doping components that must be present in the composition of gel are typically introduced at the stage of preparation of sol. Doping components are introduced in the form of nitrates or chlorides, which decompose when heated to volatile components and oxides. It modifies the oxygen-cation frame of the film of xerogel. A distinctive feature of the films of xerogels compared with materials that are synthesized in other ways is their micro porosity, due to the globular nature of colloids and gels. For example, silica gel, dried at $70{ }^{\circ} \mathrm{C}$, has a specific surface of $\sim 640 \mathrm{~m}^{2} / \mathrm{g}$.

For the Si substrates of SC, given the shape and size of these substrates, it is easier to use the process of centrifugation, which is an inherent dosing process for the fabrication of thin films on the planes that do not bend [17]. The substrates used for this process are limited by smaller size and can be reliably maintained at very large rotation speeds, that is, $1000-4000 \mathrm{rpm}$. The entire process was divided into four stages: deposition, rotation onset, rotation end and evaporation. The first three stages are sequential while the fourth one typically takes place over the entire process.

It is possible to create organosilicon xerogels, porous polyorganosiloxanes, in two ways:

1 - hydrolysis of organotriethoxylanes in organic medium (3):

$$
\begin{aligned}
& \mathrm{RSi}\left(\mathrm{OC}_{2} \mathrm{H}_{5}\right)_{3}+3 \mathrm{H}_{2} \mathrm{O} \stackrel{\mathrm{C}_{2} \mathrm{H}_{5} \mathrm{OH}+\mathrm{HCl}}{\longrightarrow} \mathrm{RSi}(\mathrm{OH})_{3} \downarrow+ \\
& +3 \mathrm{C}_{2} \mathrm{H}_{5} \mathrm{OH} .
\end{aligned}
$$

2 - in the interaction of water-alkali solution of sodium methyl siliconate and hydrochloric acid (4):
$\mathrm{CH}_{3} \mathrm{Si}(\mathrm{OH})_{2} \mathrm{ONa}+\mathrm{HCl} \longrightarrow \mathrm{RSi}(\mathrm{OH})_{3} \downarrow+\mathrm{NaCl}$.

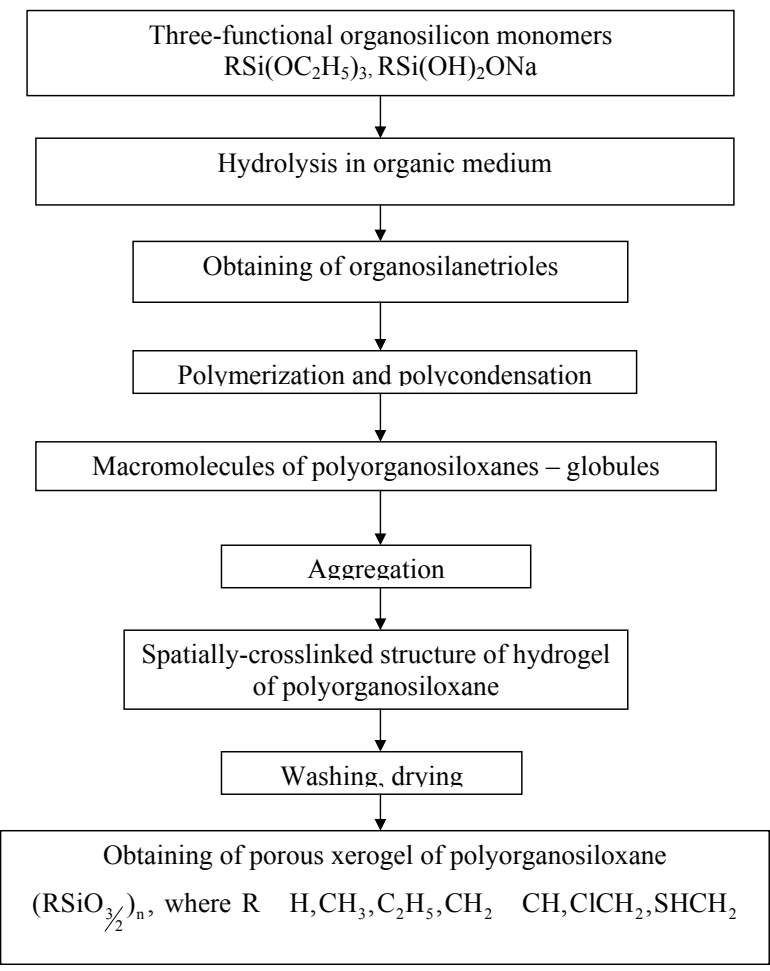

Fig. 3. Stages of technological process of obtaining porous xerogel

We used unstable organosilanetrioles that immediately enter reactions of poly-condensation and polymerization to form three-dimensional polymers - polyorganosiloxanes.<smiles>[R][Si]1([O-])O[Si]([R])(O)O[Si]([R])(O)O1</smiles>

Fig. 4. Structure of polyorganosiloxane

Actually, condensation polymer-initiating mechanism of formation of polyorganosiloxanes can be represented by scheme (5):

$$
\begin{aligned}
& \mathrm{RSi}\left(\mathrm{OC}_{2} \mathrm{H}_{5}\right)_{3} \stackrel{+\mathrm{H}_{2} \mathrm{O}}{\longrightarrow} \mathrm{RSi}(\mathrm{OH})_{3} \stackrel{-\mathrm{H}_{2} \mathrm{O}}{\longrightarrow} \\
& \stackrel{-\mathrm{H}_{2} \mathrm{O}}{\longrightarrow} \mathrm{RSi}(\mathrm{OH}) \stackrel{1}{\longrightarrow}\left[\mathrm{RSi}(\mathrm{OH})_{3} \stackrel{2}{\longrightarrow},\right.
\end{aligned}
$$

where 1 is the polymerization, 2 is the condensation.

As a result of hydrolytic poly-condensation, cyclolinear and cyclobranched low molecular polymers form (Fig. 4).

Over time, viscosity increases due to the aggregation of particles and, under certain conditions (for example, high critical concentration of the polymer), there occurs a spatially-crosslinked condensation structure of organosilicon gel.

Obtained xerogels of polyorganosiloxanes represent solid porous substances with general formula $\left(\mathrm{RSiO}_{3 / 2}\right)_{\mathrm{n}}$ (where $\mathrm{R}$ can be $\mathrm{R}=\mathrm{H}, \mathrm{CH}_{3}, \mathrm{C}_{2} \mathrm{H}_{5}, \mathrm{CH}_{2}=\mathrm{CH}, \mathrm{ClCH}_{2}, \mathrm{SHCH}_{2}$ ), with 
a very developed surface, which is an effective anti-reflective surface.

\section{Examining a surface of the obtained organic stack, created at the macro surface of a silicon substrate using a mass spectrometer (SIMS)}

We performed an analysis of elemental composition of the surface of a xerogel using the method of mass spectrometry of secondary ions (Fig. 5) after technological process of creating organic stack, grown on a silicon macro surface.

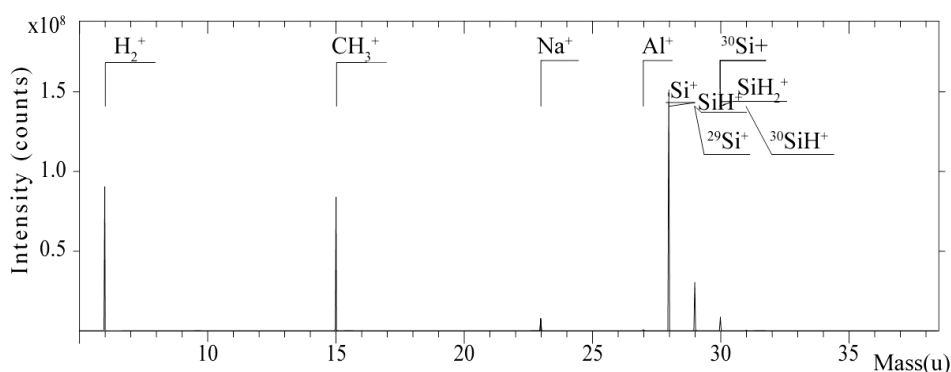

Fig. 5. Mass spectrum of the surface of porous xerogel of multicrystalline substrates of silicon, which is produced under static mode on the mass spectrometer TOF5 SIMS. Mass (u) is the mass number. Intensity (counts) is the intensity (number of pulses obtained)

The effectiveness of interaction between optical radiation and porous xerogel depends largely on the elemental composition of the surface. Of course, it is possible to form radicals on the etched surface of silicon, such as, for example, $\left(\mathrm{SiH}^{+}\right),\left(\mathrm{SiH}_{2}^{+}\right)$, etc. However, such radicals affect slightly the efficiency of energy absorption of electromagnetic radiation. The spectrum of their absorption is selective and is in the infrared range and thus it is incomparable to the absorption spectrum of silicon itself.

By analyzing mass-spectral characteristics, it is possible to determine that the etched surface of porous xerogel contains a large number of ions $\left(\mathrm{H}_{2}^{+}\right)$and $\left(\mathrm{CH}_{3}^{+}\right)$, which saturate the broken bonds of silicon. The question arises naturally on how these complexes will affect the subsequent stages of texturing the surface or its hydrogenation. As far as texturing is concerned, there are no limitations here because this stage involves a hydrofluoric acid. Aggressive fluoride can replace complexes $\left(\mathrm{CH}_{3}^{+}\right)$and provide subsequent effective etching.

Probably, as a result of substituting, there is a somewhat inhibition in the etching process in the places of accumulation of ions $\left(\mathrm{CH}_{3}^{+}\right)$. Thus, it is possible to substantiate the use of organic addition $\left(\left(\mathrm{CH}_{3}\right)_{2} \mathrm{NCOH}\right)$ as an inhibitor of the etching reaction. Chemical etching and the process of hydrogenation are conducted in a single technological cycle in order to achieve the passivation of surface by both this $\left(\mathrm{H}_{2}^{+}\right)$ and other $\left(\mathrm{CH}_{3}^{+}\right)$complexes.

\section{Discussion of results of research into creation of SC with a multifunctional multitexture}

Underlying a technological process of the formation of hybrid structures for SC is the technology of isotropic chemical etching of silicon macro textures [24]. It is impossible to form the shapes of surface with a low coefficient of reflection without the introduction of organic additions. The depth of pores can be increased by adding to the solution of surface activator. The substances that improve surface activity include organic substances. In the experiments we used various organic additions (organic acids, ketones, alcohols), which made it possible to receive macro textures with geometrical dimensions of pores within $5 \ldots 25 \mu \mathrm{m}$. It is possible to consider a porous surface (of half-ellipsoid shape) of a silicon substrate with a diameter of cell $25 \mu \mathrm{m}$ (Fig. 1) as optimal from the point of view of practical obtaining and application. Among the organic additions, only dimethylformamide (DMFA) performed better.

The presence of DMFA $\left(\left(\mathrm{CH}_{3}\right)_{2} \mathrm{NCOH}\right)$ in the etchant in the formation of texture on a silicon surface and the mechanism of its impact is quite specific. In the solution of etchant with addition of $\left(\left(\mathrm{CH}_{3}\right)_{2} \mathrm{NCOH}\right)$ there may occur intermolecular interactions of different intensity, both between molecules of the dissolved substances and the solvent and between molecules of the solvent itself.

We managed to experimentally determine the optimal conditions for obtaining macro porous surface texture of silicon substrates (the composition of etchant, duration of the process, subsequent technological operation to form a developed p-n transition, etc.). Formed by the chemical methods of treatment, the surface of a silicon substrate of PEC provides for achieving several significant advantages. The main advantage is the availability of relief (morphology) that enables carrying out of the subsequent technological phases (fabrication of organic multilayer stack using sol-gel technology). Taken together, this can form on the surface of a silicon substrate a high quality optical system to capture luminous flux.

The process of gel-formation is provided by the organic substances that are released at hydrolysis and poly-condensation of three-functional organosilicon compounds when conditions of the reaction contribute to the creation of the oversaturated solutions of polyorganosiloxanes. Such colloid-chemical systems form over time a spatially-crosslinked structure of organosilicon gel. Time and temperature of thermal treatment is important under conditions of atmospheric pressure, or close to it. In this case, liquid is removed from the gel and a monolith forms, which during subsequent thermal treatment is transformed into glass, ceramics or a porous solid body.

The benefits and features of the formation of thin films using sol-gel method include:

- possibility to obtain homogeneous film of thickness $\approx 0.1 \mu \mathrm{m}$, doped with different elements, distributed homogeneously at the molecular level in sol, gel and xerogel;

- low cost of the method, which does not require vacuum, accelerating electric field, high temperatures of treatment and considerable time costs;

- possibility of obtaining nano- or micro porous film structures.

Interpretation of results obtained in the course of examining the properties of organic stack, created at macro surface of a silicon substrate using mass spectrometer (SIMS), unambiguously indicates that in the process of synthesis of porous xerogel there occurs the introduction of atomic hydrogen to its structure and the passivation of broken silicon bonds. This is confirmed by experiments on secondary ions under static mode using the mass spectrometer. The mass-spectrum (Fig. 5) shows steady intensity (number of pulses obtained) of secondary ions $\left(\mathrm{H}_{2}^{+}\right)$and $\left(\mathrm{CH}_{3}^{+}\right)$of the surface of xerogel of a multicrystalline substrate. 
In the future, it is necessary to optimize technological process of the formation of hybrid structures for SC. The least expensive part of the technological process is a solgel method (low-molecular polymer can be replaced with a high-molecular polymer). However, a stack must be applied to the silicon surfaces with established morphology, that is, either on the macro porous surfaces or, if necessary, on the pyramidal surface.

ARC organic protective film can be applied to the surface of the stack.

\section{Conclusions}

As a result of the studies conducted, we developed a chemical process of obtaining a macro texture on the silicon substrate for SC using organic ingredients.

1. The first step in obtaining a hybrid structure was solving the problem on preserving the necessary dimension and depth of the macro texture - those were two subtasks (conditions), which must be solved simultaneously during a single technological process of etching. With a decrease in the thickness of silicon substrates, the formation of deep pores has a negative impact on the mechanical properties of the SC substrate. Studies have shown that the solutions of acids without the introduction of additions were not effective enough. To reduce the speed of etching, we performed experiments for the purpose of finding effective inhibitors in the given technological process. Taking this into consideration, it can be argued that the inhibitor DMFA participates in complex chemical processes, both in the electrolyte and on the surface of silicon. Adding a small amount of sodium salt of nitride acid leads to a significant inhibition of the processes of chemical interaction over first $30 \mathrm{~s}$ and then to a rapid increase in the speed of etching. We used various organic additions in the experiments, which allowed us to receive macro textures with geometrical dimensions of pores in the range of $5 \ldots 25 \mu \mathrm{m}$.

2 . The next step of obtaining a hybrid structure involved the synthesis of organosilicon xerogel (spatial-crosslinked structure of organosilicon gel). For this purpose, we used a sol-gel method, which makes it possible to receive the films of xerogels on the macro surfaces by immersion or centrifugation. The method of centrifugation of film-forming solutions makes it possible to form a relatively homogeneous film of thickness $\sim 0.1 \mu \mathrm{m}$ on a wafer with a large enough diameter. Xerogel partially preserves the structural properties of moist gel (that is, gel prior to drying), such as porosity, the size and distribution of pores, density of the matrix, as well as contains structural changes caused by drying.

3. To explore the surface of the resulting organic stack created at the macro surface of a silicon substrate, we performed analysis of elemental composition of the surface using the method of mass spectrometry of secondary ions in the mass- spectrometer (SIMS), following which it can be argued that the etched surface of porous xerogel contains a large number of secondary ions $\left(\mathrm{H}_{2}^{+}\right)$and $\left(\mathrm{CH}_{3}^{+}\right)$, which saturate the broken silicon bonds, in other words, the newly created ARC will be stable over time.

Reference

1. Luque, A. Will we exceed $50 \%$ efficiency in photovoltaics? [Text] / A. Luque // Journal of Applied Physics. - 2011. - Vol. 110, Issue 3. - P. 031301. doi: 10.1063/1.3600702

2. Wu, C. Near-unity below-band-gap absorption by microstructured silicon [Text] / C. Wu, C. H. Crouch, L. Zhao, J. E. Carey, R. Younkin, J. A. Levinson et. al. // Applied Physics Letters. - 2001. - Vol. 78, Issue 13. - P. 1850-1852. doi: 10.1063/1.1358846

3. Bundgaard, E. Low band gap polymers for organic photovoltaics [Text] / E. Bundgaard, F. Krebs // Solar Energy Materials and Solar Cells. - 2007. - Vol. 91, Issue 11. - P. 954-985. doi: 10.1016/j.solmat.2007.01.015

4. Yerokhov, V. Y. Porous silicon in solar cell structures: a review of achievements and modern directions of further use [Text] / V. Y. Yerokhov, I. I. Melnyk // Renewable and Sustainable Energy Reviews. - 1999. - Vol. 3, Issue 4. - P. 291-322. doi: 10.1016/ s1364-0321(99)00005-2

5. Eisenlohr, J. Efficiency increase of crystalline silicon solar cells with nanoimprinted rear side gratings for enhanced light trapping [Text] / J. Eisenlohr, N. Tucher, H. Hauser, M. Graf, J. Benick, B. Blasi et. al. // Solar Energy Materials and Solar Cells. - 2016. Vol. 155. - P. 288-293. doi: 10.1016/j.solmat.2016.06.033

6. Rahman, T. Passivation of all-angle black surfaces for silicon solar cells [Text] / T. Rahman, R. S. Bonilla, A. Nawabjan, P. R. Wilshaw, S. A. Boden // Passivation of all-angle black surfaces for silicon solar cells. - 2017. - Vol. 160. - P. 444-453. doi: 10.1016/ j.solmat.2016.10.044

7. Yerokhov, V. Coatings of the "Black-Silicon" type for silicone solar cells [Text] / V. Yerokhov, O. Ierokhova // 2016 13th International Conference on Modern Problems of Radio Engineering, Telecommunications and Computer Science (TCSET). 2016. doi: $10.1109 /$ tcset.2016.7452066

8. Won, C. W. Porous silicon microparticles synthesis by solid flame technique [Text] / C. W. Won, H. H. Nersisyan, C. Y. Shin, J. H. Lee // Microporous and Mesoporous Materials. - 2009. - Vol.126, Issue 1-2. - P.166-170.doi:10.1016/j.micromeso.2009.05.036

9. Jemai, R. Electrical properties study of double porous silicon layers: Conduction mechanisms [Text] / R. Jemai, A. Alaya, O. Meskini, M. Nouiri, R. Mghaieth, K. Khirouni, S. Alaya // Materials Science and Engineering: B. - 2007. - Vol. 137, Issue 1-3. - P. $263-267$. doi: $10.1016 /$ j.mseb.2006.12.003

10. Electronic quality improvement of crystalline silicon by stain etching-based PS nanostructures for solar cells application [Text] / L. Khezami, A. Bessadok Jemai, R. Alhathlool, M. Ben Rabha // Solar Energy. - 2016. - Vol. 129. - P. 38-44. doi: 10.1016/ j.solener.2016.01.034

11. Amri, C. Effect of Silver-Assisted Chemical Vapor Etching on morphological properties and silicon solar cell performance [Text] / C. Amri, R. Ouertani, A. Hamdi, H. Ezzaouia // Materials Science in Semiconductor Processing. - 2017. - Vol. 63. - P. 176-183. doi: 10.1016/j.mssp.2017.02.019 
12. Salman, K. A. Effect of surface texturing processes on the performance of crystalline silicon solar cell [Text] / K. A. Salman // Solar Energy. - 2017. - Vol. 147. - P. 228-231. doi: 10.1016/j.solener.2016.12.010

13. Omar, K. Effects of Electrochemical Etching Time on the Performance of Porous Silicon Solar Cells on Crystalline n-Type (100) and (111) [Text] / K. Omar, K. A. Salman // Journal of Nano Research. - 2017. - Vol. 46. - P. 45-56. doi: 10.4028/www.scientific. net/jnanor.46.45

14. Gang, M. Enhanced photovoltaic performance of polymer-filled nanoporous Si hybrid structures [Text] / M. Gang, J.-H. Lee // Physical Chemistry Chemical Physics. - 2017. - Vol. 19, Issue 7. - P. 5121-5126. doi: 10.1039/c6cp07413h

15. Jia, Y. Carbon Nanotube-Silicon Nanowire Heterojunction Solar Cells with Gas-Dependent Photovoltaic Performances and Their Application in Self-Powered NO2 Detecting [Text] / Y. Jia, Z. Zhang, L. Xiao, R. Lv // Nanoscale Research Letters. - 2016. Vol. 11, Issue 1. doi: 10.1186/s11671-016-1514-6

16. Coppede, N. Nanohybrid material synthesis by supersonic beam codeposition for solar cells applications [Text] / N. Coppede, T. Toccoli, M. Nardi // First Int. Conference on Multifunctional, Hybrid and Nanomaterials. - Tours, 2009. - P. 27.

17. Ohishi, T. Preparation and properties of anti-reflection/anti-static thin films for cathode ray tubes prepared by sol-gel method using photoirradiation [Text] / T. Ohishi, S. Maekawa, T. Ishikawa, D. Kamoto // Journal of Sol-Gel Science and Technology. - 1997. Vol. 8, Issue 1-3. - P. 511-515. doi: 10.1007/bf02436891

18. Druzhinin, A. Nanowires for Antireflective Coatings of Photovoltaic Cells [Text] / A. Druzhinin, I. Ostrovskii, V. Yerokhov, Yu. Khoverko, S. Nichkalo, Iu. Kogut // Modern Problems of Radio Engineering, Telecommunications and Computer Science, Proceedings of the 11th International Conference on TCSET'2012. - 2012. - P. 484-485.

19. Derbali, L. Electrical properties improvement of multicrystalline silicon solar cells using a combination of porous silicon and vanadium oxide treatment [Text] / L. Derbali, H. Ezzaouia // Applied Surface Science. - 2013. - Vol. 271. - P. 234-239. doi: 10.1016/j.apsusc.2013.01.166

20. Yerokhov, V. Improved porous silicon-based multifunctional materials for the solar cells antireflection coating [Text] / V. Yerokhov, O. Ierokhova // 2016 International Conference on Electronics and Information Technology (EIT). - 2016. doi: 10.1109/ iceait.2016.7500990

21. Druzhinin, A. A. Texturing of the Silicon Substrate with Nanopores and Si Nanowires for Anti-reflecting surfaces of solar cells [Text] / A. A. Druzhinin, V. Yu. Yerokhov, S. I. Nichkalo, Y. I. Berezhanskyi, M. V. Chekaylo // Journal of nano-and electronic physics. - 2015. - Vol.7, Issue 2. - P. 02030.

22. Starkov, V. V. Dielectric Porous Layer Formation in $\mathrm{Si}$ and $\mathrm{Si} / \mathrm{Ge}$ by Local Stain Etching [Text] / V. V. Starkov, E. A. Starostina, A. F. Vyatkin, V. T. Volkov // Physica Status Solidi (A). - 2000. - Vol. 182, Issue 1. - P. 93-96. doi: 10.1002/1521-396x(200011)182:1<93::aid-pssa93>3.0.co;2-8

23. Yerokhov, V. Modification of the properties of porous silicon for solar cells by hydrogenation [Text] / V. Yerokhov, A. Druzhinin, O. Ierokhova // Eastern-European Journal of Enterprise Technologies. - 2015. - Vol. 2, Issue 5 (74). - P. 17-23. doi: 10.15587/17294061.2015.40067

24. Druzhinin, A. Micro- and Nanotextured Silicon for Antireflective Coatings of Solar Cells [Text] / A. Druzhinin, V. Yerokhov, S. Nichkalo, Y. Berezhanskyi // Journal of Nano Research. - 2016. - Vol. 39. - P. 89-95. doi: 10.4028/www.scientific.net/ jnanor.39.89 